\section{Telling it like it was}

$\mathbf{T}$ here are a number of settings where one can expect (or at least hope) to be moved - at a concert, a play or in a museum —and a scientific meeting is not typically one of them. But that is where I was, along with the rest of those who attended the 11th annual RNA Society Meeting in Seattle, Washington in June, when Christine Guthrie gave an extraordinary talk about her career as a scientist upon receiving the RNA Society Lifetime Achievement Award.

Christine gave a very personal account of her path through the RNA world, one that was not straight and never easy. And although she did not dwell on the hard parts, neither did she ignore them. She described the gender discrimination, the self-doubt, the competition — and the friendships that made it possible for her to survive her own career.

Christine started her account by admitting that she had never really believed that she could make it in science. "Everyone else I saw was smarter and brimming with confidence. And while some folks may succeed only by those virtues, my greatest strength has always been my curiosity." But Christine also needed reassurance and scientific nurturing. For her, that was a long time coming, and so she began to tell her story of why she needed it and how she came to get it.

In graduate school, Christine wanted to study the biochemistry of ribosomes and asked to join the laboratory of Masayasu Nomura, the world leader at the time. He was less than encouraging. He told her, "Girls can't lift heavy rotors or stand long shifts in the cold room. They can do genetics."

She took that as a 'yes' and joined the lab. Shortly after Christine arrived, the two other female graduate students were given what were politely termed 'terminal masters'. The remaining male student gloated that they had gotten what they deserved, leaving Christine frightened and alienated. But she pressed on with her work, testing the prediction that ribosome assembly in vivo would be inherently cold sensitive. She presented her work at the Cold Spring Harbor Symposium on Protein Synthesis in 1969, but her success at the meeting only made the atmosphere in the lab worse. She decided that dropping out of graduate school was the only solution. Christine eventually returned to graduate, but then was left to fend for herself.

In her postdoctoral work at the Max Planck Institute, she encountered an even more hostile lab environment, and this time she decided to end her scientific career for good. But at just the right moment, she met Bill McClain, then a new assistant professor at the University of Wisconsin. He set her up with a dream genetic system using T4 nonsense suppressor transfer RNAs to study tRNA structure-function. They showed that most of the T4 tRNAs were synthesized as long precursor molecules, and on the basis of this work, Christine was encouraged to get a faculty position.

Christine loved her visit to the University of California at San Francisco. "By the end of the day, I had chatted with all six members of the faculty. They were-to a man - totally unbothered by the fact that I was studying this obscure system. They were looking for some- one who has fun doing good science." She was offered a job without ever having given a seminar.

"I was amazed to find such a positive scientific environment and, for the first time, I could actually imagine establishing a lab of my own - one which would be supportive and nurturing, fostering good science by promoting well-being." But when she arrived, she was besieged by female postdocs (there were no students at the time) who were desperate for a role model in the virtually all-male medical school. Her feelings of insecurity resurfaced, and she would say to herself, "Please don't watch me: I have no idea what I'm doing! I'm the one who needs help."

Nonetheless, Christine established herself as an independent investigator; but the work, as is often the case, went slowly. She was interested in studying RNase P since it also matured T4 tRNA precursors. She tried to isolate it, "but no matter what my technician and I tried, the damn thing was always contaminated with RNA. And whenever we got pure protein, the activity was dead."

When Sid Altman beat them to the punch by purifying a single essential RNA required for RNase P function, Christine seized on another project. Introns had just been discovered in yeast tRNA genes, so she took the yeast genetics course at Cold Spring Harbor and began to think about how an enzyme could accurately identify and excise messenger RNA introns.

Joan Steitz had proposed that small nuclear RNAs were required for splicing in all higher eukaryotes. But how about yeast? Did they splice, and was their mechanism of splicing conserved? Christine was certain that the answer to both questions was yes.

Using targeted gene disruption, all new students that came to the lab had to pay their dues by doing one knockout each, but alas, the knockouts had no phenotype. This dismal process continued for years. "It got so that when I showed up at meetings, even old friends became reluctant to look me in the eye. 'Surely someone should persuade her to give this up,' they muttered." At long last, the lab lucked out: a deletion of $\operatorname{snR} 7$ (which turned out to be the yeast homolog of the mammalian U5 small nuclear RNA) was dead.

Ever since, Christine, together with an impressive group of students and postdocs, has been driven by the desire to understand how the specificity and fidelity of splicing is controlled and how splicing and RNA export processes intersect. More recently, they have turned their sights to trying to understand why yeast splice. They speculate that perhaps yeast splice when they need to regulate specific proteins in response to varying environmental conditions, such as heat, cold or infectious agents. Although these scientific questions undoubtedly draw 'the best and the brightest' to Christine's lab, I'm sure they also come because they believe it is possible to have fun doing great science.

Christine also touched on the hard times she had after becoming an assistant professor. In 1976, after a very harsh midcareer review and the untimely death of a close colleague and mentor, she sunk 
into a deep depression, for which she was hospitalized. "Thinking that $I$ was the only one who was struggling to make it, I was amazed to find how many of my colleagues came to visit saying, 'I know just how you feel! This job is really tough.' This was the first time people had permission to talk about it openly."

This experience led to the formation of a problem-solving and support network, called Group, to deal with the unique challenges of life in academic science. This group has met for 30 years, and one member, Ellen Daniell, has now written a book about their experiences, Every Other Thursday (Yale University Press).

Christine's story made me think about how far we have not come. Although some progress has been made in at least recognizing gender discrimination as a problem, women still face substantial obstacles in their private, public and professional lives.

A few numbers on women in science and engineering illustrate the point. In 1999 , women earned $36 \%$ of all doctoral degrees in science and engineering. In a national analysis of the composition of the top 50 research universities, the percentage of women among full professors ranged from $15 \%$ in biological sciences to $8 \%$ in chemistry and even lower in mathematics, physics and engineering.

Women in academia face other disadvantages, such as less lab space, lower salaries and less access to research funding than their male counterparts. In January 2001, a statement was issued on behalf of nine
US research universities saying that institutional barriers have prevented women scientists and engineers from competing on a level playing field in their professions. The statement affirms that "institutions of higher education have an obligation, both for themselves and for the nation, to fully develop and utilize all the creative talent available." The signatories "recognize that barriers still exist" for women faculty and that "this challenge will require significant review of, and potentially significant change in, the procedures within each university, and within the scientific and engineering establishments as a whole."

Given that moral (and legal) imperatives require that all individuals be judged on their abilities and not on their race, gender or religious beliefs, there is much to be gained by identifying the causes of gender inequality in the sciences and devising strategies to overcome them. Of course, there is much to be said (and argued about) on both of these subjects, but that is the topic of a future editorial.

Coming back to Christine's talk, I was struck by how someone so successful and so admired had endured such difficult times, and even more by her willingness to share such personal details with us. But what most impressed me was the grace and humor with which she told her story and her lack of bitterness. In fact, Christine ended by urging us to "take advantage of one of our greatest human capacities - to be compassionate, and help one another."

Sounds like a great place to start. 